\title{
Awareness and Use of Democratic Teaching Strategy of Basic Education Teachers
}

\author{
Marie Arrianne A. Diolingo \\ Don Bosco Technical Institute - Victorias, Philippines \\ madiolingo@gmail.com \\ https://orcid.org/0000-0002-9101-1332 \\ Dexter Paul D. Dioso \\ University of Negros Occidental-Recoletos, Philippines \\ dsaunor2015@gmail.com
}

\begin{abstract}
This descriptive-correlational study examined the teachers' level of awareness and extent of use of democratic teaching strategy. This study focused on the four areas of democratic teaching: equality, freedom, justice, and participation. Moreover, this study investigated the correlation between teachers' level of awareness and extent of use of the strategy. Data were gathered from the whole population of the Basic Education Department of a Salesian school in Negros Occidental. Data analysis using mean, t-test of independent means, One Way Analysis of Variance, and Pearson Product Moment of Correlation were utilized. Results revealed that teachers have a high to a very high level of awareness of the democratic teaching strategy and a great extent of its use. The findings of this study suggest enhancement of teachers' awareness and practice of the democratic teaching strategy to address the gaps on the areas of equality, freedom, and justice considering different disciplines taught.
\end{abstract}

Keywords: Democratic Teaching Strategy, Descriptive-correlational, Salesian School, Salesian Educator, Victorias City, Philippines

Date Submitted: March 25, 2019

Date Revised: June 16, 2019

Date Accepted: July 13, 2019

\subsection{Introduction}

Education is a fundamental welfare pillar because it influences society, its culture, and politics. Therefore, it is essential for strengthening the society (Alshurman, 2015). Presently, democracy emerged as a driving force in changing the school and classroom management approach (Oyman \& Senturk, 2014). In this context, schools 
have the power to create democratic living spaces through the approaches, methods, and strategies utilized for classroom instruction.

The current Philippine Constitution Article XIV, Section 3 (Republic of the Philippines, 1987) and Education Act of 1982 (Republic the Philippines, 1982) mandate education for national development under the democratic system. Furthermore, Republic Act No. 10533 otherwise known as the Enhanced Basic Education Act of 2013 (Congress of the Philippines, 2012) provides a system of education addressing the needs of the Filipino people by advocating a learner-oriented curriculum. However, teachers are stuck on the traditional approach, even with the call for a $21^{\text {st }}$-century education, where they exhibit sole authority in the classroom.

It is noted that the success of the school rests on the educator's active awareness and leadership (Ramos, 2015). The teacher then is expected to initiate techniques and strategies that foster meaningful and relevant learning experiences. Through democratic education, meaningful experiences pave their way in embedding democratic principles and rules into open and closed goals in the schools' education program (Malatya \& Sanli, 2015). Furthermore, several educational theorists such as Apple and Beane (1995), Davies (1999), Leighton (2004), Osler (2000), and Parker (1996) emphasized the need for teachers to organize their subject-matter, their pedagogy, and their classrooms to espouse democratic education (Portelli \& Solomon, 2001 cited in MacMath, 2008).

Several studies on teachers' pedagogical knowledge reported that teachers often demonstrate an understanding of the underlying principle but failed on its implementation (Buckler, 2011; Dembele \& Lefoka, 2007; Leczel et al., 2005; Levinson, 2004; and Mhlauli, 2010). Likewise, this study cued on the recommendation of Boddy et al. (2013) to assess teachers' pedagogical knowledge and compare it with their practice. Likewise, numerous studies focused on teachers' awareness of democratic teaching strategy as a component in managing schools (Candlin \& Sachs, 2003; Clarke, 2006; Florian \& Rouse, 2009; Kincal and Isik, 2003; Oyman \& Senturk, 2014; and Walter, 1997). However, only a few pieces of literature exist on the assessment of the use of the democratic teaching strategy.

Considering the thrust of the institution under study of producing learners who are actively engaged in the society and the church that leads to the country's national development, this research forms part of the call to assess the teachers' awareness and use of the democratic teaching strategy.

Thus, the paper intended to assess teachers' level of awareness and extent use of the democratic teaching strategy in the academe and their relationship. The findings of this study focused on meaningful and relevant teaching and learning process by advocating the $7 C^{\prime}$ 's (conversing, collaborating, contrasting, conducting, conferring, co-constructing, and connecting) for democratic teaching. Such program gears in redefining the traditional classroom into a democratic classroom where both teachers and learners are education partners. 


\subsection{Framework of the Study}

In a knowledge-rich profession, teachers are regarded as "learning specialists" (Organization for Economic Cooperation and Development Report, 2015). With this role, they are expected to integrate new knowledge for professional update and growth to improve their pedagogical awareness and teaching practices (OECD Report, 2015). As key figures in the school, their instruction affects learners' success or failure (Bauyon \& Punongbayan, 2015). However, literatures reveal that teachers' transfer of knowledge into practice has some gray areas.

Several theories in the academe support claims of this study. The teacher thinking theory advocated by Christopher M. Clark espouses the idea that teachers' thought processes affect their actions and practices. Moreover, teachers' cogitation affects their judgment, their decision making and their general behavior (Clark \& Yinger, 1977). Additionally, an element of constructivism also supports this paper on the idea that teachers affect how the learners "construct" their learning (Windschitl, 2002 cited in Raikko, 2012).

Philippine education seeks to develop socially responsive, engaged, and democratic citizens to lead the country in the future. Given that goal, this academic endeavor focused on evaluating the awareness and use of the democratic teaching strategy of the basic education teachers of Don Bosco Technical Institute-Victorias for the school year 2018-2019 in the following areas: equality, freedom, justice, and participation. In relation to Kiroglu's (2013) study which focused on Social Studies teachers only, this endeavor determined significant differences on each of the areas under study through the lens of the following variables discipline, years of service, educational attainment, and department as well as the relationship between the teachers' awareness and use of the democratic teaching strategy. Thus, educational institutions serve as a training ground where learners experience society in a micro setting.

This paper theorized that teachers' awareness affects their practice. Therefore, it can be stated that awareness and use of democratic teaching strategy are directly proportional which signifies that a very high awareness leads to a very great extent of use and a very low awareness will eventually lead to a very low extent of use of democratic teaching strategy.

This academic endeavor focused on crafting a democratic teaching strategy model called the 7C's for democratic teaching which encompasses conversing, collaborating, contrasting, conducting, conferring, co-constructing, and connecting. This curricular reform gears toward the employment of democratic teaching strategy in the classroom to make teaching and learning process closer and relevant to the preparation of the Philippines'

\subsection{Methodology}

The present study made use of the descriptive-comparative and correlational approach to address the identified gaps. Furthermore, this study employed a researcher-made instrument based on the principle of democracy under the areas of equality, freedom, justice, and participation which is primarily based on the study of democratic classrooms by Kesici (2008) and Kiroglu (2013). The instrument consisted 
of two parts: part I is the profile of the respondents which gathered information about their discipline, years of service, educational attainment, and department while part II is the questionnaire on the awareness and use of democratic teaching strategy among the teachers of Don Bosco Technical Institute-Victorias. This part consisted of two sets of questionnaires. The first set of questions assessed the awareness of the teachers on democratic teaching strategy while the other set focused on the use of such teaching strategy. The respondents chose from five alternative responses according to which applies to them. The options are weighted such that a high score indicates higher awareness and use, and a low score was interpreted as having lower awareness and use of the democratic teaching strategy, respectively. The instrument underwent validity testing using Lawshe's Content Validity Ratio which yielded the score of 1.00 which imports the validity of the questionnaire. Moreover, it was subjected to Cronbach's Alpha with a reliability index of 0.96 which ensures the questionnaire's reliability.

Before the conduct of the study, the approval of the school Rector and the Principal were obtained. Upon approval, the researcher administered the instrument to the teacher-respondents in coordination with the school's respective subject area coordinators. The questionnaire was given to them during their vacant time or after school hours. Before the administration of the questionnaire, the respondents were oriented about the purpose and scope of the study, the nature, and parts of the questionnaire, and most especially, the affirmation of their willingness to participate in the study.

Several statistical tools were utilized for data analysis. For descriptive problems concerning the level of awareness and extent of use of the democratic teaching strategy, mean was used. For the comparative problems, two different statistical tools were used. In identifying the significant difference in the level of awareness and extent of use of the democratic teaching strategy concerning the variables years of service, educational attainment, and department, the t-test of independent means was used. On the other hand, One-way Analysis of Variance (ANOVA) was utilized to identify the level of awareness and extent of use of democratic teaching strategy when the respondents were grouped according to their discipline. The Scheffe Test was conducted as a posthoc test to identify the areas through which significant differences occurred. Lastly, for the correlational problem, the Pearson Product Moment of Correlation (Pearson r) was employed to find out the significant relationship between awareness and use of democratic teaching strategy.

\subsection{Results and Discussion}

\section{Level of Awareness of Democratic Teaching Strategy of Basic Education Teachers}

The data in Tables $1 \mathrm{~A}$ and $1 \mathrm{~B}$ show the teachers' level of awareness of democratic teaching strategy as very high in the area of equality with an obtained mean of 4.70 regardless of their discipline, years of service, educational attainment, and department. This denotes that Salesian educators possess higher knowledge on democratic teaching strategy in the area of equality following the foundation of Dewey's democratic disposition (Dewey, 1916 cited in MacMath, 2008). Thus, teachers are pedagogically aware that in the classroom, students should be treated equally 
and should be given equal opportunities. A study conducted in Turkey on Democratic Classroom Management which espouses that teachers are aware of the promotion and importance of the concept of equality in managing classrooms as brought to mind by almost 59\% of the survey participants supported this result (Oyman \& Senturk, 2014). Another study conducted by Kincal (2000) on teachers' level of democratic awareness and behavior found that teachers defined the concept of democracy as a human right with an emphasis on the principle of equality, which signifies teachers' awareness of equality as an essential area of democratic teaching strategy.

Furthermore, Salesian educators manifested a high level of awareness in the area of freedom in all of the variables considered as shown by their obtained mean of 4.46. Thus, Salesian educators recognize the right of the students to enjoy freedom in the classroom which is not just about mere freedom from physical constraints but freedom to choose and freedom to criticize constructively without fear of judgments and punishments (Poduska, 1996 cited in MacMath, 2008). Results of the study of Oyman and Senturk (2014) about Democratic Classroom Management supported the claim that awareness of the concept of freedom in education among teachers was emphasized among all other areas which yielded $64.9 \%$ of the respondents' responses.

In the area of justice, Salesian educators have a very high level of awareness of the democratic teaching strategy regardless of the different variables as shown on their obtained mean of 4.64. This intends that Salesian educators are highly aware of the classroom conditions needed for the practice of justice as espoused by Kiroglu (2013) in his study on democratic dispositions in the classroom which highlighted acceptance and fairness of students' treatment in the classroom.

On the other hand, Salesian educators have a very high level of awareness in the area of participation regardless of the identified variables as supported by their obtained mean of 4.51. This information shows that Salesian educators possess higher awareness of the need to incorporate teaching strategies that encourage the students to share their experiences to foster participation in the educative process (Davies, 2006; Fine, Weis, \& Powell, 1997; Ladson-Billings, 1998; cited in MacMath, 2008). A study conducted by Oyman and Senturk (2014) in Turkey, found that teachers are aware of democratic classroom management skills focused on the emphasis of participation.

Table 1A. Level of Awareness of Democratic Teaching Strategy of Basic Education Teachers

\begin{tabular}{lllllll}
\hline \multirow{2}{*}{ Areas } & \multicolumn{2}{c}{ Discipline } & \multicolumn{3}{c}{ Years in Service } \\
& Mean & SD & Interpretation & Mean & SD & Interpretation \\
\hline Equality & 4.70 & 0.36 & Very High & 4.70 & 0.36 & Very High \\
Freedom & 4.46 & 0.50 & High & 4.46 & 0.50 & High \\
Justice & 4.64 & 0.40 & Very High & 4.64 & 0.40 & Very High \\
Participation & 4.51 & 0.49 & Very High & 4.51 & 0.49 & Very High \\
\hline
\end{tabular}


Table 1B. Level of Awareness of Democratic Teaching Strategy of Basic Education Teachers

\begin{tabular}{lllllll}
\hline \multirow{2}{*}{ Areas } & \multicolumn{3}{c}{ Educational Attainment } & \multicolumn{2}{c}{ Department } \\
& Mean & SD & Interpretation & Mean & SD & Interpretation \\
\hline Equality & 4.70 & 0.36 & Very High & 4.70 & 0.36 & Very High \\
Freedom & 4.46 & 0.50 & High & 4.46 & 0.50 & High \\
Justice & 4.64 & 0.40 & Very High & 4.64 & 0.40 & Very High \\
Participation & 4.51 & 0.40 & Very High & 4.51 & 0.49 & Very High \\
\hline
\end{tabular}

\section{Extent of Use of Democratic Teaching Strategy of Basic Education Teachers}

As shown in Tables $2 \mathrm{~A}$ and $2 \mathrm{~B}$, Salesian educators have a great extent of use of the democratic teaching strategy in the area of equality regardless of all the variables under study as supported by their obtained mean of 3.92. This implies that Salesian educators have a good practice of incorporating equality in the classroom as manifested in equally treating and in giving students equal opportunities (MacMath, 2008). Findings from the study of Sleeter (2008) found that teachers in California were able to use democratic teaching in a limited form of strategic standard.

As a whole, Salesian educators have a great extent of use of the democratic teaching strategy in the area of freedom considering all the variables as shown by their obtained mean of 3.74. This finding signifies that Salesian educators have a good practice of emphasizing freedom in the classroom. This also denotes that students experience freedom in the classroom without or with minimized fear and coercion in the learning environment (MacMath, 2008). The findings above can be supported by the work of Dallimore (2004), which revealed that teachers afforded freedom to the students by letting them express their views in class.

Salesian educators have used the democratic teaching strategy in the area of justice to a great extent regardless of the four variables considered as shown by their obtained mean of 3.82. This result signifies that Salesian educators have a good practice of integrating justice among the students in the classroom and letting the students experience it. This also denotes that Bosconians are accepted by their respective teachers in the classroom as they are (Kiroglu, 2013). Literature shows that this finding supports the analysis of Oyman and Senturk (2014) that the concept of democracy in the area of justice is brought to the minds and practiced by teachers in the classroom.

Moreover, Salesian educators have used democratic teaching strategy in the area of participation to a great extent regardless of the four variables taken as shown by their obtained mean of 3.93. This result shows that Salesian educators have a good practice of promoting and participation among the students in the classroom. On the other hand, this result illustrates the participation of learners through classroom interaction (Levin, 1998 cited in MacMath, 2008). The result from the study of Bundick, Corso, Haywood, and Quaglia (2014) revealed that teachers highly encourage student participation in class through the use of varied activities and group works. 
Table 2A. Extent of Use of Democratic Teaching Strategy of Basic Education Teachers

\begin{tabular}{lcccccc}
\hline \multirow{2}{*}{ Area } & \multicolumn{3}{c}{ Discipline } & \multicolumn{3}{c}{ Years in Service } \\
& Mean & SD & Interpretation & Mean & SD & Interpretation \\
\cline { 2 - 7 } Equality & 3.92 & 0.40 & Great Extent & 4.92 & 0.40 & Great Extent \\
Freedom & 3.74 & 0.36 & Great Extent & 3.74 & 0.36 & Great Extent \\
Justice & 3.82 & 0.41 & Great Extent & 3.82 & 0.41 & Great Extent \\
$\begin{array}{l}\text { Participa- } \\
\text { tion }\end{array}$ & 3.93 & 0.43 & Great Extent & 3.93 & 0.43 & Great Extent \\
\hline
\end{tabular}

Table 2B. Extent of Use of Democratic Teaching Strategy of Basic Education Teachers

\begin{tabular}{lcccccc}
\hline \multirow{2}{*}{ Area } & \multicolumn{3}{c}{ Educational Attainment } & \multicolumn{3}{c}{ Department } \\
\cline { 2 - 7 } & Mean & SD & Interpretation & Mean & SD & Interpretation \\
\cline { 2 - 7 } Equality & 3.92 & 0.40 & Great Extent & 3.92 & 0.40 & Great Extent \\
Freedom & 3.74 & 0.36 & Great Extent & 3.74 & 0.36 & Great Extent \\
Justice & 3.82 & 0.41 & Great Extent & 3.82 & 0.41 & Great Extent \\
$\begin{array}{l}\text { Participa- } \\
\text { tion }\end{array}$ & 3.93 & 0.43 & Great Extent & 3.93 & 0.43 & Great Extent \\
\hline
\end{tabular}

\section{Difference in the Level of Awareness of Democratic Teaching Strategy}

Inferential results revealed that a significant difference in the level of awareness of Salesian educators according to their discipline exists with the obtained $p$-value of 0.020. This signifies certain variations to the teachers' level of awareness on the integration of equality in the teaching and learning process. This is due to the fact that each subject area has its specific knowledge content-based program to be followed. Results from the post hoc test revealed that significant difference lies in the ESP teachers. Furthermore, t-test results expressed no significant differences in the teachers' awareness when they were taken according to their years in service, educational attainment, and department as supported by their respective obtained p-values: $0.343,0.345$, and 0.954 . This denotes that of the mentioned variables, Salesian educators have comparable awareness.

The statistical analysis of the present study revealed no significant difference in the level of awareness of Salesian educators in the area of freedom according to their discipline, with the obtained p-value of 0.264 . This denotes that Salesian educators have the same level of awareness regardless of the subject they teach in a school which guarantees equal footing of subjects across the curriculum. Moreover, t-test of independent means results revealed no significant differences on the level of awareness of Salesian educators in the area of freedom as shown by their respective obtained p-value of: years of service (0.745), educational attainment (0.154), and department (0.299). The study of Walter (1997) supports the claim of this study that there are no 
distinctions on the teachers' level of awareness when they are dichotomized according their department.

According to their discipline, it was found that significant difference on the level of awareness of Salesian educators on the area of justice does not exist as espoused by its obtained $p$-value of 0.460 . This signifies that when Salesian educators embody the conditions through which justice and fairness work in the classroom when they are grouped according to their discipline (Kiroglu, 2013). Furthermore, t-test for independent means results revealed no significant differences on the teachers' level of awareness on the area of justice as supported by its respective obtained $p$-value: years of service (0.293), educational attainment (0.191), and department (0.959). The study of Walter (1997) supports the paper's claim that both elementary and junior high school teachers have the same level of awareness on the integration of justice in the teaching and learning process. This also denotes that teachers recognize the value of acceptance and fairness in the classroom which emphasized the school's core values.

Furthermore, One Way ANOVA results imported a significant difference on the level of awareness of DBTI teachers in the area of participation as supported by its obtained $p$-value of 0.020 . This means variation on the level of awareness among DBTI teachers when they are dichotomized into their discipline exists. Results of the t-test for independent means showed no significant difference on the level of awareness of Salesian educators on the area of participation as supported by their respective obtained p-value: years in service (0.237) and department (1.000). Walter (1997) supports this claim stating that both elementary and junior high school teachers have the same level of awareness of the integration of participation in the teaching and learning process. However, a significant difference in the level of awareness of Salesian educators when they are grouped according to their educational attainment has been revealed as supported by its obtained $p$-value of which signifies that teachers' educational attainment affects their awareness of the integration of participation in the classroom.

\section{Difference in the Extent of Use of Democratic Teaching Strategy}

One Way ANOVA result showed that there is no significant difference in the extent of use of democratic teaching strategy of Salesian educators in the area of equality which is supported by its obtained $p$-value of 0.799 . The context of the environment of the current study which is a Catholic School run by Salesian priests which holds on to the value of accompanying the young in their journey entails the practice of equality itself. Furthermore, this result means that Salesian educators do incorporate equality among their students in the classroom giving them equal opportunities and putting importance on their needs and their interests (MacMath, 2008).

Results of the t-test for independent means revealed that significant difference in the extent of use of democratic teaching strategy of Salesian educators do not exist according to their years of service (0.683), educational attainment (0.285), and department (3.23) as supported by their respective obtained p-values. In terms of educational attainment, this result may be attributed to the continued professional growth engagement of both groups of Salesian educators regardless of their pursuance of a post graduate degree. Moreover, findings regarding the teachers' years of service did not also pose a variation in the awareness of the old and the new teachers. This 
specific area is balanced with the formation given to the new teachers which includes imbibing the Salesian pedagogy with emphasis on equality among students. On the other hand, the result regarding the teachers' department is due to the fact that both elementary and junior high school teachers go through almost the same manner of basically treating every human person especially the young ones.

Results of the One-Way ANOVA indicate no significant difference in the extent of use of democratic teaching strategy of Salesian educators in the area of freedom according to their discipline as espoused by its obtained $p$-value of 0.289 . This result rests on the basic idea of the Salesian pedagogy that says "Run, jump, shout, but do not sin". Such manifestation allows the learners to express themselves freely within the limits of proper conduct. Furthermore, results of the t-test for independent means showed no significant difference in the extent of use of democratic teaching strategy in the area of freedom as supported by their respective obtained means: years of service (0.921), educational attainment (0.453), and department (0.560). Again, the scarcity of literature to support the result of the study exists. However, taking this result in light of the current study, it can be inferred that Salesian educators have a comparable and non-varied practice of freedom as part of the democratic teaching strategy.

One-Way ANOVA result revealed no significant difference in the extent of use of democratic teaching strategy of Salesian educators according to their discipline in the area of justice as supported by its obtained $p$-value of 0.104 . Salesian educators cultivate justice among the learners as a manifestation of "loving kindness" as one of the school's core values. Additionally, the result of the t-test for independent means revealed no significant difference in the extent of use of democratic teaching strategy in the area of justice as supported by their respective obtained means: years of service (0.752), educational attainment (0.258), and department (0.077). This means that Salesian educators have incorporated the conditions on the practice of justice in the classroom as identified by Kiroglu (2013).

Furthermore, according to the teachers' discipline, no significant difference existed in their extent of use of democratic teaching strategy in the area of participation as supported by its obtained $p$-value of 0.068 . This signifies that all subject teachers encourage participation among the students given the fact that performance assessment weighs more than written works and examination. When t-test of independent means was used, results showed no significant difference in the level of awareness of Salesian educators in the area of participation as supported by their respective obtained $p$-value: years of service (0.725), educational attainment (0.278), and department (0.067). This denotes that there are no differences in the methods utilized by teachers regardless of their groupings in emphasizing opportunities for participation.

\section{Relationship of Awareness and Use of Democratic Teaching Strategy}

Results revealed a significant relationship between the awareness and extent of use of democratic teaching strategy of the basic education teachers of Don Bosco Technical Institute-Victorias as supported by its obtained p-value of 0.004 . This intends that teachers' awareness leads to their use of the democratic teaching strategy in the classroom. Moreover, teachers translate learned and observed concepts of classroom management into the transformation as the country's citizens. 
On this account, there is almost no existing literature that explains the significant relationship between the awareness and use of democratic teaching strategy. However, a rich literature affirms the existence of a positive relationship between teachers' awareness and utilization of teaching strategies and techniques. Results from the study of Vail (2010) revealed the presence of a relationship between the teachers' awareness and their implementation of the 21st century teaching strategies in their respective classrooms. Moreover, a study conducted by Atian and Barandon (2016) on the awareness and utilization of assessment techniques affirms a very strong positive relationship between the teacher's level of awareness and the extent of utilization of assessment techniques.

In contrast to previous claims, findings from the study of Achor, Samba, and Ogbeba (2010) on Teachers' Awareness and Utilization of Innovative Teaching Strategies that closely characterized democratic teaching strategy found that teachers are highly aware of such teaching strategies, but only utilize few strategies effectively. This signifies that awareness did not lead to practice.

\subsection{Conclusion}

While Salesian educators generally possess high to a very high level of awareness and a great extent of use of the democratic teaching strategy under the four areas of democracy considering all four variables, certain gray areas exist on the awareness and practice of the democratic teaching strategy equality, freedom, and justice. Thus, enhancement of the teachers' awareness and use of the democratic teaching strategy is a must to address the identified gaps and to further set a uniform mindset among Salesian educators in terms of incorporating democracy in the classroom which in return will create a brand for the school.

On the positive note, Salesian educators provide the institution with the learning environment which promotes democracy as their high awareness on equality, freedom, justice, and participation which led to a great extent of use of democratic teaching strategy. This gives assurance to the learners that the classroom environment becomes a venue to freely express their thoughts, participate in the learning activities, and be treated fairly in their endeavors as students.

However, the translation of awareness into the use of the democratic teaching strategy remains a challenge for Salesian educators, but this does not deny the fact that awareness has a big role in significantly affecting the practice and use of the democratic teaching strategy.

\subsection{Recommendations}

Based on the findings, the following recommendations are advanced:

Teachers are encouraged to update themselves with the new strategies in implementing democracy in the classroom. One of the ways to do this is by continuous professional growth through pursuing graduate studies as emphasized by the significant difference found in the areas of equality and participation. The findings also call for the use of the knowledge they have gained for the improvement of the teaching and 
learning process with the help of the 7C's for democratic teaching model which will be advocated as a model for democratic education.

School administrators may create enhancement programs to address the need for teacher re-orientation as well as the re-alignment of the principles governing democratic education specifically on the areas of equality and participation under discipline and educational attainment to set a uniform mindset and practice among all Salesian educators in democratically educating Bosconians.

Curriculum developers may revisit the current curriculum and put emphasis on the practice and use of democratic teaching strategy under the four specified areas to further engage students in a meaningful learning environment. This is line with the thrust of the Department of Education on student-centered learning.

Future researchers may conduct the study in other settings such as the publicschool system and other private schools to find out more about how the awareness and use of democratic teaching strategy shape the young people in a different setting.

\section{REFERENCES}

Achor, E., Ogbeba, S., \& Samba, R. (2010). Teachers' awareness and utilization of innovative teaching strategies in secondary school science in Benue state, Nigeria. Department of Curriculum and Teaching, Benue State University, Makurdi - Nigeria.

Alshurman, M., (2015). Democratic education and administration. Procedia Social and Behavioral Sciences 176 ( 2015 ) $861-869$

Apple, M. W. \& Beane, J. A. (1995). Democratic schools: Lessons in powerful education. Portsmouth, NH: Heinemann.

Atian, D., \& Barandon, S. (2016). Awareness and Utilization of Classroom Assessment Techniques in Higher Education: The Case of a State College in Bicol. Asia Pacific Journal of Multidisciplinary Research, Vol. 4, No. 2, 51 P-ISSN 2350-7756 | E-ISSN 2350-8442

Bauyon S., \& Punongbayan, E. (2015). Instructional performance of teacher education faculty members in one state university in the Philippines. Asia Pacific Journal of Multidisciplinary Research Vol. 3 No.5, 135-143

Boddy. J., Brown. R., Durrani. N., Orr. D., Salvi. F., Westbrook. J., (2013). Pedagogy, Curriculum, Teaching Practices and Teacher Education in Developing Countries. Final Report. Education Rigorous Literature Review. Department for International Development.

Buckler, A (2011) Reconsidering the evidence base, considering the rural: Aiming for a better understanding of the education and training needs of sub-Saharan African teachers. International Journal of Educational Development, 31 (3): 244-250.

Bundick, Corso, Haywood, \& Quaglia (2014). Promoting Student Engagement in the Classroom. Teachers College Record v116 n4 2014. ERIC Journals.

Candlin, G., \& Sachs, C. (2003), Developing cooperative learning in the EFL/ESL secondary classroom. RELC journal- journals.sagepub.com

Clark, C. \& Yinger, R. (1977). Research on teacher thinking. Curriculum Inquiry. Volume 7. 
Clarke, M. (2006). Teaching diversity, social justice, and global awareness. European Journal of Teacher Education.

Congress of the Philippines. (2012). Republic Act 10533. Fifteenth Congress. Third Regular Session. Retrieved from https://www.officialgazette.gov.ph/2013/05/15/republic-actno-10533/

Dallimore, E. J. (2004). Classroom participation and discussion effectiveness : student generated practices. Journal of Communication Education. Volume 53, Issue 1.

Davies, B. (2006). Agency as a form of discursive practice. British Journal of the Sociology of Education. Volume 3. Issue 11.

Davies, L. (1999): Comparing Definitions of Democracy in Education, Compare 28 (2): 128-142

De Leon, H. (2002), Textbook on the Philippine Constitution. Rex Bookstore. Philippines

Dembele, M. \& Lefoka, P. (2007) Pedagogical renewal for quality universal primary education: Overview of trends in sub-Saharan Africa. International Review of Education, 53: 531553.

Dewey, J. (1916). Democracy and Education: An introduction to the philosophy of education, New York, McMillan.

Fine, M., Weis, L., \& Powell, L. C. (1997). Communities of difference: A critical look at desegregated spaces for and by youth. Harvard Educational Review, 67, 247-284.

Florian, L., \& Rouse, M. (2009). The inclusive practice project in Scotland: Teacher education for inclusive education. Teaching and Teacher Education, 25(4), 594-601.10.1016/j. tate.2009.02.003

Jain, V. (2008). Developing an effective teaching style. School of Educators.

Kesici, Ş. (2008). Teachers' opinions about building a democratic classroom. Journal of Instructional Psychology, 35(2), 192-203.

Kincal, R. Y. (2000). İlköğretim Öğretmenlerinin Davranışlarının Demokratiklik Düzeyi [Democracy level of elementary school teachers' behaviours]. II. Öğretmen Yetiştirme Sempozyumu, Çanakkale.

Kincal, R., \& Isik, H. (2003) Demokratik egitim ve demokratik degerler. [Democratic education and democratic values] Egitim Arastirmalari [Eurasian Journal of Educational Research]. 11, 54-58.

Kiroglu, K. (2013). Is my social studies teacher democratic? Egitim Arastirmalari - Eurasian Journal of Educational Research, 50, 127-142.

Ladson-Billings, G. (1998). Just what is critical race theory and what's it doing in a nice field like education? International Journal of Qualitative Studies in Education, 11, 7-24.

Leczel, D., Liman, M., Pomuti, H., Swarts, P., Van Graan, M. (2005) Practicing critical reflection in teacher education in Namibia. Retrieved from http://www.adeanet.org/adeaPortal/ publications/newdoc/adea_05/05_namibia_en.pdf

Leighton, R. (2004). Teaching citizenship education: A radical approach. London: Continuum International Publishing Group.

Levin, B. (1998). The educational requirement for democracy. Curriculum Inquiry, 28, 58-78. 
Levinson BA (2004) Hopes and challenges for the new civic education in Mexico: Toward a democratic citizen without adjectives. International Journal of Educational Development, 24 (3): 269-282.

MacMath, S. (2008). Implementing a democratic pedagogy in the classroom: Putting Dewey into practice. Canadian Journal for New Scholars in Education/Volume 1, Issue 1

Malatya, M., Sanli O., (2015). The significance of establishing democratic education environment at schools. Journal of Educational and Instructional Studies in the World. Volume 5. Issue 2. Article: 01 ISSN: 2146-7463

Mhlauli, M.B. (2010). Social studies teachers' perceptions and practices of educating citizens in a democracy in upper classes in primary schools in Botswana, Ph.D. thesis, Ohio State University.

Osler, A., (Ed.) (2000). Citizenship and democracy in schools: Diversity, identity, equality. Sterling, VA: Trentham Books Ltd.

Oyman, N., \& Senturk, I. (2014). Democratic Classroom Management in Higher Education: A Quantitative Study. Educational Sciences: Theory

Parker, W. C. (1996). Teaching Democracy: Unity and Diversity in Public Life. New York: Teachers College Press.

Portelli, J. P., \& Solomon, R. P. (Eds.) (2001). The erosion of democracy in education. Calgary, AB: Detselig Enterprises Ltd.

Raikko, B. (2012). Characteristics of effective and engaging secondary social studies instruction in an era of rising accountability for teachers and students.

Ramos, A. (2015). Methods and teaching strategies used by teacher education faculty members in one state university in the Philippines. Asia Pacific Journal of Multidisciplinary Research, Vol. 3, No. 5, 36 P-ISSN 2350-7756 | E-ISSN 2350-8442

Republic of the Philippines. (1987). The Constitution of the Republic of the Philippines. Retrieved from http://www.officialgazette.gov.ph/constitutions/1987-constitution/

Republic of the Philippines. (1982). Batas Pambansang Blg. 232 (Education Act of 1982). Retrieved from https://www.lawphil.net/statutes/bataspam/bp1982/bp_232_1982. html

Robles, Chan. (2019). Batas Pambansa bilang 232. Chan Robles Virtual Law Library. Retrieved from http://www.chanrobles.com/bataspambansabilang232.htm\#.XSxMw-tKjIU

Sleeter, C. (2008). Teaching for democracy in an age of Corporatocracy. Teachers College Record, Volume 110, Number 1. California State University, Monterey Bay.

Vail, L. (2010). Teaching in the $21^{\text {st }}$ century. Watson School of Education University of North Carolina Wilmington

Walter, P. (1997). Social Studies in Elementary Education. retrieved from https://eric.ed.gov

Windschitl, M. (2002). Framing Constructivism in Practice as the Negotiation of Dilemmas: An Analysis of the Conceptual, Pedagogical, Cultural, and Political Challenges Facing Teachers. Review of Educational Research. 